\title{
Religious Conversion
}

When I arrived at the pueblo joven-based home of Camila, a member of Friendship Ministry, one of the first things I learned was that her conversion to Protestantism in Korea had resulted in disagreements with her family over how to run their businesses in Peru. Camila's mother was Catholic, and the two of them were arguing - transnationally-over the ethics of selling beer in the store on the first floor of their home. As was the case with the other Peruvians I knew who had converted to Protestantism in Korea, Camila abstained from alcohol and saw Catholicism as being lax in its moral underpinnings partly because Catholics were allowed to drink. She not only abstained, but she also wanted to help improve the spiritual and economic lives of her family and community by not providing alcohol to them.

I had met Camila just a month earlier at her church in Korea where she was an enthusiastic member of the Spanish-language congregation. At twenty-three, she was one of the younger Peruvian members. She was in love with her Peruvian boyfriend whom she had met in Korea. She was excited about my project and offered to show me where she sold accesorios after work on the streets of her factory town and then to arrange a visit with her family when I traveled to Lima the following month. Many people in Camila's family had worked in places like Korea, Japan, Chile, and the United States. She wanted me to see the store she had built with her remittances and visit her mother and a few of her siblings who still lived in or near the family home in a pueblo joven in Lima.

I took a long combi and taxi ride from my apartment in San Miguel, and as we approached her neighborhood, I saw that few of the streets were paved. There were 
signs this area was improving though, including curbs, sidewalks, and traffic lights that almost sparkled with their newness. When my taxi arrived, Camila's sister, who had also worked in Korea years earlier, came outside to meet me. We walked a short distance to the family house and storefront. Camila's mother owned the house, but the little bodega was actually Camila's store, constructed with remittances she had sent from Korea. Similar to how Lily's relatives referred to their home as "Lily's house" (in chapter 2), Camila's sister made a point of referring to the store as Camila's-even though Camila had never been there (just as Lily had never been in "Lily's house").

The store was a narrow rectangular structure made of cinderblock running alongside a wall of the house. Like many other small stores I saw in Lima, it did not have a door for customers to walk through but rather just a window where they could pass money and receive merchandise. The window was covered in metal bars to protect the store from potential robbers. ${ }^{1}$

I stood on my tiptoes to try to see their wares. Typically stores like this had shelves of things like snacks, individual rolls of toilet paper, and small packets of laundry detergent and shampoo displayed against the back wall. I jumped back when a woman suddenly shouted at us from inside the store.

"Who is that?" the woman yelled.

"Camila’s friend from Korea, Mamá," Camila’s sister said.

There was no response.

That is when I noticed their mother was inside the store. She was short and only the top of her hair was visible through the slot where customers passed their money and got their change.

Camila's sister continued chatting with me about Korea and my research and moved aside every time a customer approached the window. It was before noon, but everyone who came to the store left with beer-from single bottles to entire cases.

I probably would not have even noticed that everyone was buying beer if Camila's sister had not seemed embarrassed about it. She smiled apologetically and said, "Camila has agreed, for now, to sell beer," she told me. I guessed then that Camila must have introduced me as a friend from her Protestant church.

"If we don't sell beer, we might as well close down!" her mother yelled from behind the bars, as if she was still in the middle of the fight with Camila.

Her sister made no comment on that topic. Instead, she invited me inside the house, a two-story structure. With the store completed, Camila was now in the process of sending money to build up a second business-an internet café. They were turning the front room into a place for computers but they were also still using it as a living room. She told me Camila did not want the internet customers to look at pornography-a rule she had no problem with but thought might hurt business. Her mother flatly refused, however, to comply with Camila's directive to stop selling beer in the store. 
Camila's mother came out of the store through a door along the living room wall and sat in an upholstered chair. She sat in silence as I talked to Camila's sister about her own migration to Korea years before. When I asked them who in their family had first migrated to Korea, her daughter looked at her mother.

She told me her husband had gone to Japan in the early 1990s and started another "compromiso" (commitment). He had apparently met a woman in Japan and stopped contacting them.

I could see how the family would have a complex relationship with the remittances sent from Camila and her siblings. Remittances had allowed the family to survive and even led to their upward mobility, but remittances also had scattered the siblings around the world and were a reminder of their abandonment.

They asked about my family, and when her mother found out that my husband was from Mexico City, she asked me to bring her an image of the Virgin of Guadalupe on my next trip. She specifically wanted one that had been blessed by a priest from the Basilica, a sacred Catholic site that luckily was located near my mother-in-law's house.

I agreed to bring her the image, but I knew that Camila might not approve. That is because in addition to alcohol, many of the Peruvians who had converted from Catholicism to Protestantism in Korea had come to believe that the importance attributed to the Virgin Mary and saints (such as El Señor de los Milagros) in Catholicism in general and Peru in particular angered God. They interpreted displaying images of saints and virgins to be worshipping false idols - and believed they had contributed to the financial and spiritual demise of Latin America.

By the time I returned to Peru the following year, Camila had also returned. When I called her family house in Lima, I had to remind her where we knew each other from because she was surprised to hear a foreigner's voice on the phone. Once she recognized me, she said how happy she was to hear from someone she had known in Korea. She told me that she had gotten pregnant and decided to return to Peru instead of trying to raise an undocumented child in Korea. She and her son were living with her mother until her boyfriend, who was still in Korea at the time, could save enough money to construct a house for them in Lima. She asked me to come to the house and then join everyone for her birthday party at a nearby restaurant. In addition to her own family, which was Catholic, her future in-laws, who were Protestant, would also attend.

As soon as Omar and I arrived at their house, Camila's mother came rushing down the stairs asking if I had brought "Mi virgencita" (the image she wanted of the Virgin of Guadalupe). When I took the framed image out of my bag, she unwrapped it, held it to her chest, and said happily, “'La gringa cumplió! [The American girl came through!]." Camila stood by and looked embarrassed. “Mamá!” she said. It was difficult to tell if she was embarrassed by her mother's devotion to the image of the Virgin, or because she had referred to me somewhat derogatorily as "the gringa," or having done all of that before saying "hello." I never 
found out as we rushed out of the house to get taxis to the restaurant. They did at least pause long enough to show me that the internet café had been completed. I noticed signs posted on the wall-ones that had been typed and printed out on computer paper-that said things like, "No swearing."

During Camila's birthday lunch, held at a lively family-style parrillada, or barbeque restaurant, it became apparent that something had changed in the family dynamic since my previous visit and Camila's return.

We sat at a long table that ran along the front window of the restaurant. Camila's mother, her mother's friend, and Camila's siblings sat on one side of the table, while Camila's in-laws clustered around the other end. Camila directed me to sit with her near the middle of the table. Her sister and brother-in-law had ordered the food and drinks for the table, which included several elevated metal platters overflowing with slices of roasted steak, anticuchos (marinated beef hearts), rabbit, cuy (guinea pig), and pork. Scattered between the trays of meat were platters of French fries and salad as well as big bottles of Coca-Cola and Inca Kola. When the waiter placed icy pitchers of sangria on each end of the long table, Camila gave her sister a frustrated look. I did not hear her say anything about it, but she looked miserable for most of the meal.

I guessed that pitchers of sangria were a flashpoint especially today because of the presence of Camila's future in-laws. It was one thing to have family disagreements about alcohol, but another to have people witness it. I realized that since the last time I had seen Camila and her mother, their temperaments had switched.

Camila's mother responded happily to the arrival of the pitchers and held up her glass for Camila's future brother-in-law, Elias (who told me he was the only member of his family who was not religious), to fill. Elias had also worked in Korea years prior, and while we waited for the food to arrive, he had been telling me a fascinating story about how he had managed to talk his way out of the airport in Tokyo during a layover after being deported from Korea. Once outside the airport he had found a pay phone, called cousins who lived in Fukuoka, and stayed in Japan for nearly ten years before being deported to Peru the month before this party. When he offered to pour me and Omar a drink, Camila reacted quickly.

"You don't have to drink that," she said.

I turned the drink down, touched by Camila's kind gesture to protect me.

"You don't drink?" her mother asked disapprovingly from across the table.

I paused, not sure how to answer. "I do," I said, and immediately felt Camila deflate next to me. "But not today."

An hour into the meal, the pitchers on the in-law side of the table were still full, and the outside of the glass dripped with condensation. Camila's family's side of the table, which now included Elias, was lamenting their empty pitchers between boisterously telling stories. The in-law side was quieter and more serious.

After a while, Camila's mother asked the in-laws to pass their full pitchers down the table if they were not going to drink them. To Camila's obvious dismay, they 
did. Ignoring Camila's embarrassed looks, her mother offered both me and Camila's mother-in-law a glass, which we accepted. In this setting, I was not sure which was the most culturally appropriate response: drink or refuse. It also seemed that since Camila had returned from Korea, it was not clear who was ultimately the highest-ranking person at the table and what the expectations were for Camila, her family, and even me as the interested visitor with muddled allegiances.

Either way, spending time with this family that was now both Catholic and Protestant and had the addition of potential in-laws was more complicated than it was prior to migration. I not only saw the ways religious conversion had transformed these families, but also how the family dynamics had changed since Camila was no longer a migrant sending economic and social remittances from abroad. Although currents of disapproval and approval still ran through everyday choices, such as how to run the family store, and how to treat guests at special events, Camila no longer seemed to have much of a voice in defending her position, even at her own birthday party. She had converted in Korea, but now that she was in Peru, it was proving difficult to live her life the way she wanted, let alone persuade her family to change their lifestyles. The stakes had changed and so had the players.

Conversions were a way for migrants to negotiate their place in the world and to influence the ways others saw them. Once Camila had left Korea, the value systems between her worlds in Korea and Peru diverged. She could not get her family to see the world from her perspective because without economic remittances she no longer had as much negotiation power over her family.

Although Camila's story was just one example of the many configurations of religious belief and family dynamics I observed during my fieldwork, I found that people's stories and experiences of religious conversion provided a window into the ways migrants understood and tried to change not only their own status but also that of their families and communities and in turn influence the meanings of their migrations and how others saw them. In this chapter, I explore the ways Peruvian migrants converted to or changed religion or renewed their faith in South Korea and discuss how in converting themselves and attempting to convert others, they negotiated and reconfigured the meaning of their migrations; their relationships with their families, peers, and churches in Peru and Korea; and their place in the world.

For Peruvian migrants, Korea provided a backdrop that infused both Protestant and Catholic church participation with more opportunities to advance one's cosmopolitan conversions than other migration destinations would have. Their exceptionalism in Korea not only allowed migrants to gain cultural capital at an accelerated rate-in the form of experiences and leadership positions in their churches-but also gave them the platform to try to influence others to see them as cosmopolitan leaders rather than as economic migrants. I discuss how some migrants interpreted events in their lives and migrations through the framework of respuestas, or answers from God, and in doing so, they portrayed their religious 
conversions as being more valuable than money. Sharing respuestas at various levels-with their families, peers, and the public-gave them cosmopolitan experiences and changed the ways others saw them in Peru and South Korea. By examining how people's understanding of things like conversion, migration, money, and transnational ties between Peru and Korea were intertwined, I attempt to go beyond a utilitarian view of migrants' religious conversion and focus on the ways conversions that happen in transnational spaces create and complicate conventional understandings of global hierarchies and configurations of power.

\section{RELIGIOUS CONVERSION AS A PATH TO BECOMING LEADERS IN KOREA}

Before the global financial crisis, I centralized my fieldwork on the various communities that the clergy from the Catholic Church visited, partly because that gave me the greatest access to the Peruvian community as a whole. Over time I noticed that Peruvian congregations from Korean evangelical Protestant churches had taken a larger role in the Peruvian migrant community, not only as spiritual centers but also as alternative sources of resources and information for migrants. As I started spending more time with Protestant groups, I expanded my focus to compare the ways Peruvians experienced religious conversion within the various religious communities.

To capture the different types and degrees of "religious conversion" people experienced during their migrations to Korea, I include new, rejuvenated, and renewed levels of belief and participation in Catholic and Protestant churches. By new beliefs, I mean people like Camila who told me they had arrived as Catholics, or with no religion, and then joined a Protestant church in Korea.

By rejuvenated beliefs, I mean people who arrived in Korea as nonpracticing Catholics or Protestants, found a corresponding church, and became more passionate about participating in events and becoming leaders. I frame rejuvenation as a form of conversion because for most Peruvians, being a Catholic or Protestant in Korea was different from being either of these identities in Peru.

By renewed beliefs, I mean people who came from Protestant families in Peru but felt they had found the "true gospel" in Korea. ${ }^{2}$ Jheremy, one of the migrant leaders from Friendship Ministry, explained it to me like this, "The Cristiano [Protestant] in South America is a partial Christian, but the Christian in Korea is a total Christian." When I asked Peruvians with renewed religious beliefs to describe their conversion experiences, they told me they had left Peru because they were looking for something, and when they got to Korea, they "found a connection with God," "learned to let God into [their] heart," or "learned what it really meant to trust in God." Although they had started as Protestants, people who experienced a renewal of faith in Korea often saw it as being a drastic transformation or conversion. 
Rather than try to interrogate the "authenticity" of these religious conversions, I am interested in exploring the transnational milieu in which the conversions happened. Migration to Korea was vital in creating the context for these religious conversions. Not only did other destinations for Peruvian labor, like Japan, not have the religious infrastructure to provide spaces for these communities to form, but since Korean churches were embarking on their own cosmopolitan conversion projects looking for global destinations and converts, Peruvians also became more desirable partners than other groups of more numerous or documented foreigners.

Korea provided Peruvian migrants numerous opportunities for conversion and religious participation not available to them in Peru-and that included being Catholic. In describing his background, one man I spoke to told me that he was Peruvian and therefore Catholic. I took this statement as a naturalization of his Peruvian and Catholic identity. To be fully Peruvian one must be Catholic. While the majority of the Peruvians I met at Masses had grown up Catholic, many of them told me it was "in name only," and they had not attended Mass regularly nor had they completed the necessary religious rites of passage to be a full member of the church, such as getting confirmed. Having missed these events as children was a source of shame for many.

However, in Korea, the Catholic clergy was openly offering the chance to remedy this problem. Above the Mass schedule in the March 2007 Catholic newsletter distributed to Peruvians in Korea was written: "Everyone who wants to prepare to receive their sacraments that they have not received yet are invited." They even included a kind of Sacrament FAQ section in the same issue of the newsletter defining and describing Baptism, First Communion, and Confirmation-perhaps questions they knew many of their parishioners were afraid to ask aloud. "What happens when we are baptized?" it begins. "Nos convertirmos en HIJOS DE DIOS [We turn into CHILDREN OF GOD].” In that same issue of the newsletter a man from Norte Chico wrote an article about how while growing up his uncles had bullied him for not getting baptized, and now that he had completed the process in Korea he had ended thirty-six years of shame. He wrote, "Now I am baptized, my best Christian Catholic life begins. What I was missing, not only is joy for me but for my spirit and my family. . . Now I'm ready, with a lot of faith to . . renew things." Being in Korea gave participants like him the opportunity to become fully Catholic and therefore Peruvian-something they could not do in Peru.

I noticed in 2009 that fewer people seemed to be attending Mass than during my previous field trips in Korea. When I asked Padre Ignacio about it, he told me that people were now more scared to leave their houses and attend regularly, but that the interest in participating was still high. He had recently baptized twelve Peruvians - all adults - in one day in Dongducheon. That was not the first time he had done a group baptism for Peruvians in Korea, but it was the largest group he had personally done. He said he thought this enthusiasm to participate in the church was because their relatively small numbers made them feel like they were part of a 
community. He also pointed out that rites of passage like Baptisms or Confirmations were usually reserved for children and would have been too humiliating to attempt as an adult in Peru. In Korea, though, it seemed congregants experienced a certain religious liminality where surrounded by a small community of people in a similar situation they were permitted to break the rules of age convention and undergo a ritual that was required, but taboo for them, as an adult Catholic.

In addition to defying taboos, Catholic rituals done by undocumented migrants in Korea tended to take on a new urgency. For example, in May 2009 I attended a Mass in Seoul where a man in his seventies was baptized, confirmed, and received his First Communion all in one day. He was a quiet man I recognized from Masses where he accompanied hymns by playing the cajón, a Peruvian wooden percussion instrument. When I talked to the nuns about how they had spent the previous months helping him prepare for his rites of passage, I noted the sense of urgency around the process. Not only was there a risk he could be deported before completing the steps, but more importantly they were also planning this event for the day a Korean bishop, who was also a nuncio (a papal ambassador) visiting from Rome, would preside over those rituals for the migrants. Everyone who was baptized or confirmed that day not only got to do so with a nuncio but also received a gift from the Vatican-a crucifix blessed by the pope. I got the sense this type of opportunity would have been a rarity for most converts in Peru (or Korea for that matter).

When I was in Norte Chico, I attended a Mass to compare it to the Spanish-language services in Korea. There were multiple Masses held every Sunday in Norte Chico, and at the one I went to, every pew in the cathedral was full. However, the attendees seemed much less cohesive. There was no message from the priest about the community, or at least I could not hear it over the chatting of the teenagers in the back where I was seated. As soon as Mass was over, people streamed out of the church. In contrast, Masses I attended in Geumcheon and Suwon felt like lively bimonthly reunions of friends. The clergy led interactive Masses where congregants participated in the sermon by reading passages or answering questions geared specifically toward applying the day's lesson to migrant life in Korea. Congregants and clergy stayed afterward to chat over meals of Peruvian food that a rotating group of volunteers had prepared. During the end of my first summer of fieldwork in 2006, the Mass ended with a sixtieth birthday celebration, regarded as an auspicious birthday in Korean culture, for Padre Ignacio. We moved to the rooftop of the church where we ate Korean food, listened to música tropical, and taught the French priest to dance merengue.

At another lively, but not quite as memorable, Mass in Suwon, I ran into Hermana Luz, a Peruvian nun in her early thirties who I had met in a factory town a few years prior. As we drank Chilsung Cider from small paper cups and waited for the food to be served, I asked her why she thought so many people regularly attended Mass here when they never had in Peru. She said, "I think that they have 
a new religious experience here in Korea. They can be together and share. It is something special."

Rafael, who had been a church leader (un responsable) in Korea before he was deported, shared Hermana Luz's opinion that the religious community in Korea was special. In fact, he told me that even though the church had been a central part of his life for the seven years he lived in Korea, after he returned to Norte Chico he rarely attended Mass. When I asked him if going to church in Korea had been different from going in Peru, he said, "Yes! In Korea, they [the clergy] called you personally. It depended on the nun. The Koreans [referring to Korean Protestants who went around to factories to evangelize] supported you too. They would visit the factory and invite us to church."

As these sentiments show, being undocumented migrant workers in Korea changed the significance of workers' faith and religious participation from being something normatively Peruvian in Peru to something that made them special and gave them a productive opportunity in Korea. To practice Catholicism in Korea was to join a community, be recognized as special, and also to have opportunities that would be difficult or impossible to have in Peru-such as getting confirmed as an adult or even receiving a crucifix blessed by the pope.

Perhaps the most significant thing that set Korean churches apart from those in Peru were the leadership opportunities they created for Peruvian participants. Each of the three religious groups I worked with had leadership positions for Peruvian migrants that emerged because of their status as undocumented migrant workers from a small community.

The Catholic clergy had appointed two or three men and women in each of the communities they visited to be "los responsables de las comunidades [the people responsible for the communities].” The June 2007 Catholic newsletter featured the photos of "los responsables" with a headline stating they would "help everyone else get close to God and join together with others to help themselves." These lay leaders organized the weekly group meals after Mass and were the contact people in their area between the clergy and the migrant workers. They also seemed to receive special attention from the clergy and attended retreats where the larger group was not invited.

Friendship Foreign Ministry had various leadership positions for their undocumented congregants that had potential for upward mobility beyond Korea. While some were small rotating jobs in the Sunday service, like leading hymns, others were more permanent and included "professional assistance" where select migrants received scholarships to study theology abroad. In the December 2003 Friendship newsletter, which was written in English, Korean, and Spanish and seemed to be directed at both the internal audience of the congregants and potential Korean donors from larger churches, a Korean pastor wrote about the origins and future of the Peruvian congregation and their plans for world evangelization. He wrote that in July of that year the Peruvian congregation had gotten so large-to thirty 
people and growing - that they were able to offer a separate Spanish service for the first time, and he had decided to elect five leaders from the group. He and the Peruvian leaders had decided they should "learn from the Korean churches overseas" and "preach the gospel with the same courage as the Korean immigrants. At their workplace, they should consider themselves as missionaries. . . Not only should they evangelize to their foreign co-workers, but to their Korean employers, as well." Ultimately, they decided to begin a new era of "world evangelism," making their church the hub of a "nexus of missions." By the time I started conducting fieldwork in the church four years later, two of the migrant leaders had returned to Peru and enrolled in a prestigious seminary with scholarships facilitated through Friendship's connections. I later visited one of the migrant-leaders-turned-seminary-students at the mission church he helped run alongside Korean missionaries in a pueblo joven in Lima. Another leader, Jheremy, was still in Korea and in charge of the Peruvian congregation. He was learning Korean and English and did simultaneous translations of the main sermon, which was in English. He told me he was waiting to be invited by a church in Paraguay or Ciudad Juárez, Mexico, for missionary training. ${ }^{3}$

At Nazarene, nearly all of the Peruvians I met introduced themselves as some kind of leader in their church and in a larger world evangelization project. Pastor David, who had been a pastor before he came to Korea as a migrant worker, had an official position with the church that other parishioners told me came with a salary and free apartment. He and his wife were even listed as the official delegates for the territory of Latin America in the megachurch's program for the annual missionary convention I attended in 2007. There were many other types of leadership positions for Peruvians as well, though. The back of the program for the weekly Sunday sermon listed five evangelists and five ministers with different jobs like programming and entertainment. Nazarene members routinely dressed formally-suits and ties for the men and dresses and heels for the women-and carried name cards with their names, contact information, and titles, such as "Evangelist." Unlike the Peruvians who worked in factories, most Nazarene members sold accessories at night and were free during the day. They attended classes at church on weekdays for things like multicultural evangelism, and they held their own bible study forums. They also played a leadership role in the church's multiday missionary conference, staging large events and carrying the flag for Peru in a parade of nations at the opening ceremony. ${ }^{4}$ Even those Nazarene members who were not listed as official evangelists or missionaries told me they were going to be the ones to construct Cristo Vive, the religious center they planned to build in Peru.

For Peruvian migrants, attending church in Korea was different from attending church in Peru because they were undocumented and at the convergence of multiple cosmopolitan conversion plans. The state's plans-which legally excluded them partially because their small numbers made them inconsequential and their cultural distance from Korea made them undesirable-interacted with the churches' 
plans. In these environments, their foreignness was desirable and their imminent departures gave them a sense of exceptionalism that increased the urgency and degree to which they received services and attention.

By 2009, the attendance at and frequency of Catholic Masses had decreased, but the number of Korean Protestant churches with Peruvian migrant members had risen. Like renewing one's Catholic faith in Korea, to become part of a Protestant church in Korea was also a way to find a sense of community while accessing resources and leadership opportunities. However, perhaps more importantly, since it had become increasingly difficult to survive in Korea as an undocumented migrant, participating in Korean Protestant churches was a way to obtain some social protections while also working toward a future that was different from being an economic migrant. Korea's mission-minded churches facilitated the training of Peruvians to be pastors and missionaries and helped them launch new churches and careers in Peru and elsewhere.

\section{PREDESTINED MIGRATIONS}

One evening as I helped Paty, a member of Nazarene, carry her cases filled with costume jewelry to her usual selling spot near a subway station in Seoul, she told me that her son's birth in Korea was not just a blessing but also a respuesta, or personal message from God, that her migration to Korea was predestined. "In Peru I had so many problems," she told me. "Mental, physical, and spiritual problems. I couldn't have a child. I was barren!" she said, laughing. Her son, Julian, who had just turned two years old, was shouting tearful protests at us in Korean as we tried to get him settled in his stroller. Paty cheerfully raised her voice over Julian's cries to tell me that she saw his birth as a sign that she was on the correct path God had laid out for her. "I accepted God in Korea, and ... I found solutions to all of my problems," she said. "Now I know that I came to Korea in order to have a child."

From an outsider's perspective, Paty's migration did not look particularly successful. She was forty-one, had been in Korea for six years, and seemed to be struggling for money. Julian's father had been deported to Peru the year before and stopped contacting them. To make matters worse, the only day care in the area that would accept undocumented children was closed during the hours when Paty could find regular employment. This left her little choice but to sell jewelry on the street to make ends meet. Despite these problems, she felt her pregnancy was part of the many respuestas she was receiving as a result of moving to Korea, converting to evangelical Protestantism, and becoming an active member of Nazarene.

Like many other Peruvians I met in Korea, Paty's story of conversion was intertwined with her story of migration. Through her conversion, Paty had come to see her Catholic upbringing in Peru as spiritually and financially toxic, and Korea, with its high number of Protestants and growing economic prowess, as particu- 
larly blessed by God. When I asked how she had chosen to look for work in Korea over other destinations like Argentina or Chile, which at the time she had arrived in Korea were more popular and accessible destinations for Peruvian labor, she looked at me incredulously and said, "I come from a family of idol worshippers." She described the way her mother displayed images of El Señor de los Milagros in their living room in Lima. In her Korean church she had come to see these images and her family's Catholicism as factors contributing to her family's poverty. She explained how after converting she now felt that her choice to migrate to Korea had not really been about looking for money but was part of God's plan to help her get away from the Catholic-dominant Peru, convert to Protestantism, and then save her family and eventually all of Latin America from spiritual and financial ruin through her evangelism.

This framework required some imagination. First, the number of Protestants in Peru had been on the rise since at least the 1950s, and while Korea was one of the most Christian countries in Asia, Catholics and Protestants only made up about 20 percent of the population. ${ }^{5}$ However, it made sense through the lens of a type of prosperity gospel found in many Korean Protestant churches, including Nazarene, that "material prosperity is evidence of God's favor, either preordained or earned." ${ }^{6}$ In her research on Korean-led evangelization and development efforts in Africa, Ju Hui Judy Han discussed the neoliberal and geopolitical nature of prosperity theology. She wrote, "South Korea's wealth ... was seen as evidence for God's favor, while 'African' poverty was interpreted as a result of insufficient Christian faith."' While Han's interlocutors cited Islam, AIDS, and tyranny as further evidence of God's disfavor with Africa, Peruvians talked about alcohol abuse, infidelity, and the worshipping of false idols as both evidence and causes of Peru's (and Latin America's) economic and social suffering. When explaining this framework to me, one of Paty's friends, Hector, told me, "Korea is the school and we are in training." Part of this training was learning how to be better Christians and also how to interpret the world and one's past experiences within this linear geopolitical prosperity theology framework that placed Korea on top.

"Respuesta" was a term that came up a lot in my Korea-based field notes starting in February 2009 when I met the Nazarene Peruvians. They told me that if I read the Bible I would find many answers (respuestas). However, as I spent more time with them, I found they used respuestas in more creative ways too. They described respuestas as answers, messages, or signs set out for them by God, either to reward them for having made a correct life choice, or to guide them in the right direction in the future. Through reading these respuestas, they determined that not only was their migration to Korea predestined and about something more important than wanting to make money, but that Peru was actually more blessed than other nations-including Korea. And rather than being unimportant as their legal status and small numbers might indicate, Peruvian migrants in Korea were exceptional. 
For example, Miguel and Jaime, two Nazarene members, told me that God had specifically protected them from deportation because they were Peruvian Cristianos. Jaime had been walking near his apartment with three undocumented friends (from Peru and Southeast Asia) when plainclothes officers suddenly appeared and grabbed his friends. Only Jaime was able to escape, but the others were detained and subsequently deported. He said that in this terrifying moment he realized that he was particularly blessed and that he needed to attend church more often. He interpreted this reprieve as a true respuesta, both a sign that he was destined to be in Korea (as a Peruvian) and that he was a good Cristiano (as an individual).

Miguel interpreted his relative invisibility as a Peruvian migrant as a respuesta and a way to avoid deportation. He described how even unauthorized Korean vendors had gotten kicked out of the alleyways where he usually sold accessories. But when the officers saw him, they just left him alone. For Miguel, other foreigners (and even Koreans) being removed around him was evidence that he was destined to be in Korea, and that he belonged there even more than some other people. Peruvians have no control over their legal status in Korea, but they can change the reading of their status. Their telling shifted the narrative of their migration from one of tragic invisibility, where the migrant and migration pattern is unimportant, to one of strategy, where God uses invisibility as a way of protecting and recognizing an important person.

The use of respuestas located them in larger Christian movements and also marked them as Peruvian migrant converts. It is common for other evangelical groups to look for signs from God. For example, in their article "Pathways of Migrant Incorporation in Germany," Nina Glick Schiller and colleagues found that like other "born-again modernist" churches worldwide, the West African congregants in the German churches they studied also "emphasized signs and wonders" and saw "prosperity and success as proof of a 'righteous Christian life." " In 2019, I emailed three Cristianos who had converted in Korea to ask if they had used the term respuesta prior to arriving in Korea. They said yes, and that it was a term used by Protestants and not Catholics in Peru, but that their use of it increased significantly after they converted in Korea. ${ }^{9}$ In contrast to the frequency of the use of "respuesta" to describe these kinds of special events, no one in my field notes ever described the things that happened to them as "miracles" (milagros). This was perhaps a conscious decision to distance themselves from Catholic icons in Peru like El Señor de los Milagros. Since respuestas were improbable and unexpected events, they could certainly be understood as miraculous, ${ }^{10}$ but they were foremost valued for being tangible indications of one's engagement in a successful dialogue with God. Describing events as respuestas made the recipient seem like a partner in a successful negotiation rather than a needy recipient of a chance windfall.

Friendship parishioners also used the term respuesta, but much less frequently, at least when talking to me. They also discussed finding the path God had created for them as having an economic value, but they talked about it a little differently 
than Nazarene members. For example, one day I was talking to Jheremy and said, "Some people told me that they thought they came to Korea to make money, but money was not really what they were looking for. They were looking for something else. What do you think?"

He scoffed and said, "The Peruvians who come to Korea come for money. Nobody comes just to experience something, they just want money. Why? Because they need to support their lives economically . . . but here in Korea they realize what God wants. Right?” Then he went on to say how being in Korea helped people discover something they could not learn in Peru-that God has a path for people that might be different from what they think they want. He said:

Only leaving Peru can one realize that. We have the example of [two migrant leaders from Friendship]. They had a vision, Korea. And what was their vision? Save money! But what did they find? They did not find what they asked for. They found something else. They found the vision God had for them. [When they went to Peru] they brought money for their ticket, that is it. Why? Because the church had sent them [paid for them] to study. The church paid to help them set up their churches.

Although using slightly different terms, like Nazarene parishioners, Jheremy and other members of Friendship came to see their migration decisions as being linked to their conversions." They also believed that their life paths had changed as a result of coming to Korea and that information about God's plan had become accessible to them through their partnership with their churches.

Respuestas helped migrants define the global configuration of their migration and conversion journeys in Korea because they are like virtual travelogues that record migrants' routes and roots and account for the changing cultural meanings migrants gain while creating and traveling these particular trajectories. ${ }^{12}$ As linguistic anthropologists argue, the telling of a life story can itself be a life-shaping event. ${ }^{13}$ Respuestas, like other narratives, "situate narrators, protagonists, and listener/readers at the nexus of morally organized, past, present, and possible experiences. ${ }^{14}$ For transmigrants, or people whose actions, decisions, and concerns create social fields that connect and surpass national borders, ${ }^{15}$ through their telling, respuestas reflect, constitute, and reconfigure the way communities are connected. Respuestas reflect the delicate linkages and boundaries of a person's portion of the global world and constitute social fields that not only connect Peru and Korea but also heaven and earth, and the past and the future. ${ }^{16}$

\section{THE FORUM}

Respuestas became like capital in many Cristianos' cosmopolitan conversion plans for improving the options available to them beyond being economic migrants and for promoting their religious conversions as being more valuable than money. They presented respuestas as evidence of being on a path chosen by God and also 
as a way to convince others to see them as important figures. They shared respuestas at church as part of their testimonios (testimonies), or personal stories of salvation, in conversations with nonbelievers, and with each other during informal occasions such as prayer meetings.

I had originally met Paty at a prayer meeting Nazarene Peruvians called "The Forum," which they held at different members' apartments on Tuesday afternoons. The first forum I attended was held at the house of a man from Lima named Juan who was in his early forties and was in a relationship with a Korean woman. I never got a chance to meet her and guessed she was at work during these afternoon forums. ${ }^{17}$

Their apartment was tucked back in a working-class neighborhood of villastyle apartments in the shadows of a college area of Seoul where many Nazarene members lived. The apartment was humble by Korean standards. It was cramped, and the front door was flimsy like a bedroom door. However, it had its own kitchen and attached bathroom, making it better equipped for handling a crowd than the other Peruvian-occupied apartments I had visited in this area. Most others had to share communal bathrooms, which were located in separate buildings and consisted of squat toilets and a faucet.

When I arrived around 2:00 p.m. I was greeted by three Peruvian women in the kitchen cooking Peruvian food. They invited me to go into the living room and join the other forum members who were sitting on the floor around two Koreanstyle tables. In addition to Paty there were about seven people squeezed into the little living room, which was already packed around the edges with things like bookshelves, big cardboard boxes, and fans. In the shuffle to clear a spot for me to sit, someone kicked off the leg of one of the tables, which was only connected with packing tape. The leg must have gotten knocked off regularly as no one reacted beyond picking it up and sticking it back in place. Many of the foreigners I knew in Korea-from Peruvian migrants to American English teachers-had furnished their apartments with used items Koreans had placed on the curb as trash. I figured this table was one of those reclaimed items.

As soon as I sat down someone handed me a plate of food, and the group began asking me questions.

"Are you Protestant?" someone asked me right away.

I said no.

"So, you are Catholic," Carlos, a twenty-two-year-old wearing suspenders said in the tone of someone who had just won a bet.

"Tampoco," I said, meaning I was neither of the two. Everyone looked confused.

Ximena, the woman who had invited me here, had just dropped me off and left. She had needed to take her daughter to the doctor. I started explaining my research project to them in detail, afraid they did not know what I was doing there.

"We know about your project," a woman said, cutting me off. 
"This forum is about spiritual problems first, then about earthly things," Juan said. "I urge you to open your heart and accept it not like it's a story or a study," he said firmly.

I told them I appreciated them allowing me to participate and I looked forward to hearing what they wanted to share. My reason for being there did not surprise them, but they did seem to have trouble fitting me-a nonreligious Americaninto their geopolitical divine framework of the world where the United States was usually ranked with South Korea as a Protestant nation benefiting from God's favor. They looked truly surprised when I told them many Americans were not religious.

During this discussion Juan's brother arrived from Dongducheon with a young woman from the Philippines named Giselle. The group was very happy to see them. Something had happened to the pair that had inspired them to come here, but no one told me what it was. They both looked exhausted. Giselle looked like she had been crying.

Giselle spoke English, but not Spanish, and her boyfriend did not speak English well.

"I knew it wasn't a coincidence that you were here," Paty said to me happily. "It was a respuesta. You can translate what we say to Giselle!"

At the time, I was a little confused by this, but I understood what she meant when I started attending Nazarene's Sunday services and saw that they always included a prayer request for translators on the back of the pamphlet they created with the day's sermon and schedule. The fourth prayer was, "May God raise up [levante] translators, interpreters, and materials for the message in the trainings." They had asked for a Spanish to English translator. Instead of having to find me, I had sought them out and stumbled into their weekly prayer forum at exactly the right time. Paty saw that as a respuesta materialized.

They all got out Spanish-language Bibles and little spiral notebooks they carried with them to church to take notes and took turns sharing their testimonios and asking God for guidance. As soon as I realized they wanted me to translate entire paragraphs of speech at a time I quickly got out my own field notebook and pen so I could remember each person's whole message.

"Please pray that God reveals my role in His plan," each member would say in a slightly different way as they went around the circle. They shared the respuestas they had received from the previous week's prayer group or during their time of conversion. In either case, participants interpreted their respuestas as signs that they were successfully navigating the plan that they believed God had laid out for them: to travel to Korea, learn the true gospel, and change their lives (and their family's lives) for the better. Like Paty, they described their journeys to Korea as part of a path that God had already chosen for them long before they were born, but one that they did not understand until they converted to Protestantism in Korea. Their respuestas indicated that they were correctly following 
the plan and were also viewed as a reward for being good Cristianos. Since they had chosen the correct path, they were able to stumble on these rewards and simultaneously receive respuestas, or clues as to where God's path led next. For most, signs seem to suggest the path led to Peru where they would help to create Cristo Vive, the religious center they planned to build in partnership with Nazarene in Peru. ${ }^{18}$

The testimonios had the flow of well-rehearsed speeches, as though they had told them many times, but there were also some parts directed specifically at me (as a scholar from the United States with a Mexican husband) and Giselle (as a migrant worker from the Philippines), seemingly to help us see our lives and presence in Korea within God's larger plan.

In addition to telling me I could be a translator for their efforts in Korea, they told me my husband and I could study and take the evangelio to Mexico. ${ }^{19}$

With Giselle they addressed her visible sadness and the common money concerns they shared as foreign workers. Although some Nazarene parishioners talked about their lack of factory work as a respuesta because it gave them the time to study at church and do evangelizing work, this did not mean that they had stopped thinking about money. In fact, money appeared in most of their conversion narratives.

One woman thanked the forum for helping her see that God had changed her life in Korea despite struggling to make money. "The fight continues," she said. "The forum has helped me see that God has come. I am getting respuestas. Before [in Peru], I cried a lot and did not know why." This comment about no longer crying was directed at Giselle.

Some talked about the profitable work they had sacrificed in order to attend the forum. For example, Stefano, a musician who supported himself by performing Andean flute music at festivals and selling CDs and accesorios, told us how in order to come to the day's meeting he was missing out on a festival that would have paid $\$ 6,000$. This statement did not cause a noticeable reaction in the room, although many people in attendance had been unable to find any work and were accepting handouts from their church. Part performance, part confessional, and also unverifiable, Stefano's contribution to the prayer group highlighted the ways he saw respuestas and his religious training as being worth more than money.

Others tried to help Giselle see her respuestas by locating her in their geopolitical divine hierarchy framework.

"It hurts me to hear Giselle can't be happy. But I have to say that the Philippines suffers from idolatry," one woman said. She told us she also had a Buddhist mother and that had led to her spiritual problems.

Giselle, who had been quiet until this point, interjected that the Philippines was not a Buddhist country and there were a lot of Christians there. I translated that and the woman paused, but only changed course slightly.

"No one is born bad," she said. 
When it was Carlos's turn, he told a story of sin in Peru and redemption in Korea.

"God is real," he began. "In Peru my life was only about beer and girls. But they only brought me one day of joy. Then I was back to misery. When I got to Korea I only thought about money. But then, I realized I had spiritual problems. Now I know that I came to Korea to find God. Respuestas are coming for me!" He finished with emotion.

The general details as well as the arc in Carlos's story were common in testimonios I heard from both men and women in Korea. Many narratives involved either indulging in alcohol and sex in Peru or in Dongducheon or Itaewon before being miraculously transformed after conversion. However, after spending more time with Carlos, I came to doubt that he had been a serious womanizer or drinker. Despite the vagueness of his story, Carlos, like the other men and women at the forum, became emotional during his turn to share. I realized that respuestas could be more symbolic than factual - and still avoid being dishonest. Respuestas helped to illustrate the overall message that converts had come to believe and wanted others to believe as well-that their own presence as a Peruvian in Korea was part of a larger, more important global plan in which their Korean church had an advantage. They were in Korea as a result of divine intervention. Further, in this version of the story they were not needy recipients of charity, but were important co-contributors guiding this plan to fruition.

\section{EXCHANGING ECONOMIC AND COSMOPOLITAN CAPITAL}

Many of the conversions discussed in this chapter involve negotiating relationships between two or more things: Catholicism, Protestantism and "true" Protestantism, selling beer or not selling beer in the family store, understanding an unprofitable migration as a failure or as being predestined. Like all relationships, these conversions were infused with power. Identifying respuestas not only gave migrants the language to frame and position themselves in their migration journeys but also power in negotiating the terms of their transnational relationshipswith their churches, families, and peers.

In July 2009, Paty told me about her strategy for creating the respuestas she wanted for herself and her family. I had been visiting Paty and Julian in their tiny studio apartment when the discussion turned to her mother and family in Peru. Between her toddler, the poor conversion rate, and her choice to become an evangelist, she could hardly afford to send her family any money. "My mother knows I have my own child to take care of now," she said.

Then she turned to a topic she frequently asked me for advice on-her plan to bring her sister Marisol to Korea. This idea had initially confused me because by mid-2009, the chances that a Peruvian could successfully pass through 
immigration as a tourist had become very slim. However, Paty explained that she did not want to have her sister try to enter as a tourist, but to come by way of a student visa. Paty assured me that Marisol had a degree in environmental engineering, and I had met quite a few students from Mexico and Colombia working toward master's and bachelor's degrees in Korea, so I knew that getting her a student visa was plausible. Paty called me frequently to ask about the student visa. After investigating online regarding the different options for Latin American students, I asked Paty if Marisol wanted to study the Korean language or obtain a degree in a specific topic.

"No!" Paty said, speaking in the quick laughing pace she always used. "She wants to sell accesorios." To me this plan sounded complicated at best and threatened to be a financial disaster at worst. Paty would have to pay thousands of dollars to arrange for her sister's documents, round-trip ticket, and living costs. Even if Marisol made it to Korea, she would not make much money selling. The financial crisis had resulted in more Koreans losing their jobs and entering the accesorios market, and the increased deportations surrounding the upcoming G-20 summit had made the streets where Paty and her church members sold extremely dangerous for undocumented migrants. Why would Paty invest in such a doomed plan when she had such little extra money?

"If she is in Korea, I can teach her the gospel," Paty told me finally.

This was truly a negotiation. Rather than send economic and social remittances to her family in Peru, Paty was using her economic remittances to bring her sister to Korea where she thought she would be more likely to convert. Her sister wanted to work in Korea and make money, and Paty wanted her to convert. The student visa was a compromise.

As much as this plan was about her sister being saved, I saw it being more about Paty demonstrating that she could be a successful evangelizer. Paty had been taking missionary and evangelism classes at Nazarene for the past two years, but I do not think she had been able to convert anyone. Part of the problem was that since she was a monolingual Spanish speaker, Korea offered a limited audience for her to evangelize. Basically, her main options for evangelization were her family at home and other Spanish-speaking migrant workers and foreigners in Korea (including me). She excitedly told people about the signs indicating that I had started to convert-such as looking happier at forums.

Paty's efforts to bring Marisol to Korea, and convert her, seemed to make her feel like she was doing valuable work. As anthropologist Simon Coleman points out, attempting to convert someone is a self-constitutive act that is not just about transforming others but about transforming the self. ${ }^{20}$ If Paty's plan was a success, her respuesta would not be more remittances but to be able to tell her sister about God in person. Physically bringing her sister to church services on Sunday and positioning herself as the person who had saved her would be an added bonus. By attempting to convert others-whether or not they listen or are converted-the 
converter receives a new sense of purpose and a new way of gauging one's success and sense of power through their efforts to convert.

This was a conversion of economic capital for cultural capital that was multidirectional. By sending economic capital and financing Marisol's migration, Paty stood to gain the embodied capital of becoming and being seen as a successful evangelizer. By accepting Paty's gift of economic capital with strings attached, Marisol stood to increase her own economic capital by working in Korea. These religious and economic conversions were a way to negotiate the constantly changing environment of their global worlds.

\section{PERU DAY}

I saw this power negotiation on a grander scale at various events where Cristianos interacted with Spanish-speaking clergy from the Catholic Church and members of the Peruvian embassy and consulate. There were many occasions for this to happen, including community events organized by Nazarene Peruvians who had extended invitations to the Catholic clergy and Peruvian dignitaries and the annual embassy-sponsored Peru Day celebration.

Although I heard a priest say the Peru Day celebration was not a religious event, the ones I attended were held at a Catholic Church in Seoul. They also began with a Catholic Mass and finished with entertainment and a Peruvian meal.

In 2009 there were a couple of changes. The seats of the church were filled with Catholics, members of Nazarene, and Peruvians I had never met before. I stood with Padre Diego at the back of the church as there were no seats left. He explained that this year, in addition to the embassy splurging on a pisco sour toast, they had decided to invite the Cristianos to participate in the proceedings in an official capacity. Knowing that some of the Nazarene members, like Stefano, were professional musicians, Padre Diego had asked them to perform traditional Peruvian flute music to entertain the crowd. Then Nazarene's undocumented Pastor David would be invited to say a few words alongside other leaders such as the Peruvian ambassador to Korea. The Cristianos respectfully sat through the Catholic Masswith the exception of Paty's son, Julian, who kept getting up and running around the pews yelling. As Paty chased after him, she saw me standing against the back wall. She stopped briefly to chat and inform me that she attributed Julian's disruptive behavior to bad spirits that were flying around the church. She thought the bad spirits came in part because of the large painting of Christ on the cross behind the altar-which she thought was idolatrous. I just nodded in sympathy. It was hot and crowded in there, and Julian was one of the only children.

After the Mass, Padre Diego looked annoyed as the Cristianos began to diverge from plan and evangelize to the crowd. In the pause during which organizers passed out plates of food and trays of shot-sized pisco sours, the Cristianos walked around greeting everyone and inviting them to attend their church. They also 
distributed little "Good News" booklets outlining the church's teachings, which they had purchased from a small stand in Nazarene's lobby. In the preceding months I had already received four copies of this booklet-in English and Spanish-and whenever I tried to refuse a new one, they encouraged me to take it for a friend. A Peruvian woman I had not met before handed one to Padre Diego and to me. ${ }^{21} \mathrm{He}$ accepted it, albeit with a look of astonishment on his face.

After the meal Stefano and other members of Nazarene went up on the raised area behind the altar (which doubled as a stage) and got out electric guitars and an electric drum kit. Rather than perform Andean flute music, they proceeded to play a full set of Christian rock music. The Nazarene parishioners in the audience stood up and clapped along joyfully to the songs. The priest, nuns, and much of the audience started to leave a few minutes into the show. At the end of the event the only people left to take photos with the ambassador were the Peruvians from Nazarene.

I took this as a power play by the Cristianos to reclaim Peruvian space that was normatively Catholic. By handing out booklets even to the priest, who it seemed obvious to me would never convert, showed that this proselytization was about negotiating the terms of their relationships with these institutions: the state and church. By refusing to play Peruvian Andean music-which they knew how to play, and had seemingly agreed to play-and opting for gospel music instead, they changed the Peru Day narrative. They were not normal Peruvian migrant workers-they were changing the story and establishing themselves as leaders.

\section{NOT JUST FAKING IT}

This effort by Cristiano converts to position themselves as leaders who had made authentic conversions, rather than as recipients of charity, was something I saw on a weekly basis in Korean Protestant churches. A common critique I heard from migrants, clergy, and families in Peru was that Cristiano converts were "just faking it" in order to get financial rewards.

When I asked Padre Ignacio what he thought of Catholic Peruvians converting to Protestantism, he said, "They might go there for a free meal, but it doesn't go deep."

As Padre Ignacio's comment indicated, for many Cristiano converts and their detractors, the most salient of these rewards was free food after church services. On many occasions I attended the Spanish-language Catholic Mass in Gyeonggi Province and watched, alongside the priest and nuns, as parishioners slipped out of the cathedral right at 6:0o p.m. so they could make it over to Friendship Ministry in time for an extensive, hot buffet-style meal that came complete with kimchi and dessert. These meals were purchased and prepared by a rotating group of affiliated Korean churches who came early to set up the food trays and stayed to try to socialize. ${ }^{22}$ From my chats with the Korean visitors, this meal service seemed to be a chance for the relatively affluent members of those churches to do charity 
work with needy migrant workers. While Friendship also offered weekly sermons in many languages, free medical clinics, haircuts, and language classes, for many attendees the biggest attraction was the free Korean food.

To avoid characterizing the free food as a utilitarian approach to drawing new members to the church, the leaders of Friendship framed it as a potential respuesta for those who come to the church to eat. They hoped that even those people who thought they were coming just for the free food would ultimately realize God had used food as a tool to bring them to church. Ideally, they would stay for the right reasons and eventually convert because they would become true believers. For example, Jheremy recalled the behavior of Friendship's early Peruvian congregation around free food:

They came just as the sermon ended to get in the food line. The pastor said, "Those Peruvians always come just to eat!” That's what she said! Sundays they played soccer all afternoon. They all showed up in their soccer clothes to eat. . . The church was empty during the sermon. But at dinner, it was completely full. That actually had a huge influence on them joining the church. Food. Because from that time, many of them learned about the gospel, right? So, it's actually something that brings them to God. The food brings them.

Jheremy argued that while hundreds of Peruvians had come just for the food, dozens eventually started coming for the gospel. This system seemed to work too, because the Spanish-language congregation was constantly decreasing due to immigration raids, but the church baptized and cultivated a contingent of Peruvian parishioners who continued to identify as Cristianos even after departing Korea. Thus, free food indirectly strengthened the church's ability to expand its community in Peru.

I asked Friendship's Pastor Sarah why they had been so successful in converting migrant workers. I was curious to find out if she shared many of the Nazarene Peruvians' opinions that they had been sent by God to Korea to be converted. Her frank answer surprised me. "When migrant workers are in trouble it's easier for them to find Jesus," she said with a shrug, "It's true." Like Jheremy, she hoped Peruvians came for the food and stayed for the gospel. However, in her view food is a way of meeting the basic needs of poor, isolated, undocumented migrants first, while having the secondary benefit of making them receptive to conversion. Her response also highlighted that she was comfortable with the negotiation in converting others.

While free food attracted some migrant workers, it repelled others. In fact, as the members of Nazarene saw it, they had specifically turned down the charity from other churches-including free food-in order to show the authenticity of their conversion. Originally, nearly the entire Peruvian congregation of Nazarene had been devoted members of a small neighborhood Pentecostal church in Seoul. After a chance meeting with a Latin American pastor affiliated with Nazarene, 
they had all stopped attending their small neighborhood church without giving an explanation. When people talked to me about this, they seemed embarrassed about it. They justified their actions by saying that the pastor at the small neighborhood church had only wanted to meet their financial needs (by giving them food, employment, or offering to help them open a Peruvian restaurant in the neighborhood) rather than attending to their spiritual needs. "God provides!" Ximena told me when justifying why she had stopped attending his church. She was nearly crying. "The pastor doesn't understand that. He thinks it is all about free bread rolls and milk," she said, motioning toward her refrigerator, which was also a gift from his church. Although she had accepted many gifts from the small church, she appeared offended that the Korean pastor would think she would attend his church just because of the availability of free food.

What Ximena and the other members of Nazarene rarely discussed, however, is that they also received free meals at their new church. In fact, the meals were more frequent and formal than I had seen at the other churches. The church gave them tickets that allowed them to eat for free at the cafeteria across the street from Nazarene on the days of their classes and on Sundays between the Korean service in the morning and the Spanish service in the afternoon. However, they seemed to regard this food not as a form of charity or as a way to attract new members, but as a way for them to achieve their ultimate goals of becoming global leaders since having lunch available on campus maximized their time at the church. Portraying the food as a tool to help them become leaders rather than as charity for undocumented workers in need illustrates the ways they negotiated the terms of their conversions and relationships with their churches and peers.

\section{MISSIONARY ENCOUNTER-CONTROLLING}

THE MESSAGE

The telling of their conversion stories helped Cristianos change the value of their migrations from being about the struggles of undocumented economic migrants to being about the achievements of global figures connecting Korea and Peru. Depending on the sites where they told these narratives, and who was present to listen, they could not only reconfigure their sense of self but also their reputations in Peru and the global hierarchies they were navigating as undocumented migrant workers.

One example of this came from an event Paty and the other Nazarene Peruvians organized in August 2009 called the "Missionary Encounter." Multiple members of Nazarene invited me to the luncheon, explaining it was where attendees could meet Latin American missionaries who were in town for Nazarene's World Missions Conference, a multiday event that would take place at a sports stadium in Seoul.

That Friday, soon after arriving at the expensive Mexican restaurant in Itaewon where the luncheon was being held, I realized that while it was a chance to meet 
Latin American missionaries, it was primarily set up as an evangelizing event targeted at Seoul's Spanish-speaking population. This mainly consisted of migrant workers, soldiers serving in the US Army, foreign language teachers, diplomats, and businesspeople. However, despite heavy promotion and the promise of free food and entertainment, apart from a table full of missionaries and their spouses, a few Korean members of the church, and many Peruvians from Nazarene, the restaurant was fairly empty. I sat with Paty, who had also invited me and saved me a seat at her table. She wore a formal dress and heels despite the sweaty heat of the August afternoon.

Isac, a leader in Nazarene, was the emcee, and as the meal was served, he stood on a small stage in the front of the restaurant and gave opening remarks. There would be musical and theatrical performances as well as presentations by missionaries. The first performers to take the stage were Peruvians from Nazarene. Some performed gospel songs; Stefano played traditional Peruvian flute music; there was a one-act play about the importance of God in a marriage; and then, finally, a video the Peruvians had made about how Latin America was failing because it had not yet turned Protestant. The video, which featured images of hurricanes destroying the coast of Mexico and children drinking alcohol in the slums of Lima, spoke to their plans to literally "save" Latin America-make it more economically profitable, healthier, and free from God's wrath - through the evangelization efforts they would lead.

After the video, various guest speakers, including Nazarene's Pastor David, went up to the microphone and shared their testimonies. They described various respuestas they had received from God while in Korea as well as their experiences of conversion. As they spoke, two Peruvian teenagers who had grown up in Korea and attended an American Christian school in Dongducheon stood on the edges of the stage and provided the non-Spanish speakers in the audience with a simultaneous translation from Spanish to English.

One of the first guests invited to speak was an ambassador from a Latin American country who was stationed in Seoul. In addition to being an ambassador, he was also an evangelical pastor and was very passionate about his experience in Korea and about the luncheon. The Peruvians sitting at my table all clapped as the ambassador listed the respuestas he had experienced while living in Korea, the biggest of which had been regaining his sight in a Korean church after nearly going blind. He described how a fellow church member, a Korean man, had touched him and said, "Heal!" and he had been healed. "God has the palm of his hand over Korea!" the ambassador told us to great applause.

Although the luncheon was set up as an evangelizing event, none of the Peruvians seemed upset about the poor turnout of potential converts. The scheduling of the event-Friday afternoon-when most Spanish speakers in Seoul would be working and could therefore not attend, seemed to indicate that perhaps nonbelievers were not the Peruvians' target audience in the first place. In fact, the most 
important audience for their respuestas, performances, and evangelizing videos seemed to be Korean church leaders, the visiting missionaries, and each otherpeople who were already converted. By organizing the event-even when there was no one to convert-they positioned themselves as the leaders and spokespeople of the Spanish-speaking community in Korea, and the ones who would launch a new mission from Korea to Latin America. Rather than limiting themselves to Korea, it seemed they wanted their videos, performances, and respuestas to reach a global audience, and they brought their own translators to make sure everyone understood their message. Regardless of the initial intention of the luncheon, their Korean church stood to gain its own level of multicultural prestige by having enough Spanish-speaking members to hold such a large-scale event. Further, preparations for this multilingual event illustrated the church's potential for extending its global missions to Peru, a place that they had yet to reach, and where they could demonstrate their superior place in God's hierarchy through the Peruvians conversions.

This message even reached audiences in Peru six months after the "Missionary Encounter," when the Peruvian ambassador to Korea at the time appeared on a Peruvian-based radio show available online called "Peruanos en el Exterior" (Peruvians Abroad) to discuss the Peruvian community in Korea. ${ }^{23}$ In this episode about Peruvians in Korea, rather than using the interview to discuss the origins of the migration pattern, or the increasing economic connections between the two countries (which would develop into a Free Trade Agreement in 2011), the ambassador highlighted the presence and activities of the Peruvian Cristianos. Even before the hosts asked the ambassador a question, she jumped into the interview by characterizing Korea's Peruvian population as consisting of three main groups: (1) a small group of professionals, (2) a large group of undocumented migrant workers, and (3) a "strong" group of Christian evangelists who work closely with Peruvian communities on social projects.

The way she divided Peruvians into these three discrete groups is significant for two reasons. First, the Cristianos were presented to the radio audience as the "strongest" and most important group despite only making up a fraction of Korea's Peruvian population. The ambassador did not mention that groups two and three were the same people: the evangelists were also undocumented migrant workers. In her telling, the Cristianos did not come across as an undocumented and therefore problematic labor force. Instead, they were characterized as worldly spiritual entrepreneurs. This is precisely the image Cristianos try to create of themselves in their recounting of respuestas. Second, the ambassador's reference to "social projects" supported by Cristianos is a little misleading. These projects include launching mission churches like Cristo Vive and spearheading plans to convert their families and combat the toxicity they saw as a result of living in a predominantly Catholic nation like Peru. Together the Peruvian Cristianos and the ambassador worked to present respuestas as selfless social projects rather than the personal 
aspirations of undocumented migrant workers, thereby giving the migration pattern a new level of prestige and value.

I did not get a chance to interview the ambassador, so I can only guess at her motivations for using this radio appearance to present the Peruvian Cristianos as the leaders of the entire community and highlighting the value of their contributions. My guess is that she wanted to put a positive spin on the story of Peruvian migration to Korea, and that the Cristianos had succeeded in making themselves and their activities acutely visible to her. ${ }^{24}$ In my participant observation with the Peruvian community in the months preceding this interview, I noted that the Nazarene Cristianos had organized, were featured speakers or performers, or had attended at least three events alongside the ambassador or consul general. While the foreign priests or nuns spoke for and represented the Catholic community at these events, the Peruvian Cristianos usually spoke for themselves. They introduced themselves as pastors, evangelists, and missionaries, not undocumented workers. In this "official" capacity, and within the particular political and religious transnational networks they were helping to create, they did not seem afraid of making themselves visible in Korea.

Therefore, no matter her motivation, the ambassador's recognition of undocumented Peruvians as contributing to Korea and social progress in Peru more generally is quite significant. Through the radio program, Peruvians of Nazarene were rendered visible and credited as creators of transnational projects and leaders of their community.

\section{CONCLUSION}

In this chapter I have presented various examples of how Peruvian migrants underwent religious conversions in South Korea, and how they communicated the significance of these experiences with their families, churches, and communities in Peru and Korea to show how conversion was a way that people negotiated the value of their migrations and selves as migrants in an unstable global climate. For both Catholic and Protestant converts, unique opportunities for forming communities and establishing leadership opportunities within their churches happened because of, rather than in spite of, their status as undocumented migrants from Peru with little chance of remaining in Korea. Their conversions would have been much different in Peru, with less urgency and different stakes. Further, as Camila discovered, conversions to the value of one's status and capital were more difficult to maintain and negotiate once migrants had returned to Peru. However, as I tried to convey with Paty and Marisol's story, conversions are multidirectional and cannot fail when viewed as part of emerging, ongoing plans.

Converts did not portray their legal and economic instability as moments of failure, but rather as the inspiration for them to make creative conversions to the value of their economic capital and religious experiences. I have shown that by 
interpreting events in their lives as respuestas, they formed and promoted themselves as co-navigators (along with God) in their global journeys. Through taking on leadership roles in forming events like Peru Day, the Missionary Encounter, or even refusing to acknowledge the items they received from their churches as charity, and instead believing them to be respuestas that furthered their preparation to be leaders, they interacted with and shared billing at events with ambassadors and professional missionaries.

The religious conversion experiences I discuss here are also essentially negotiations in the meaning of relationships-between Peru and Korea; between Catholic and Protestant; whether a migration is predestined or doomed; whether one is a leader or a recipient of charity, a successful or a failed migrant, a daughter or a remitter. Like all relationships, these conversions were infused with power, partial truths, negotiations, and tension. Since conversions are about power, they can reconfigure the value of the self, others, things, and the relationships among all of these.

In the next chapter I take a closer look at migrants' plans and projects as cosmopolitan conversions to explore the ways people interpreted and changed the significance of their lives in Korea. 